Agricultural Journal 14 (4): 60-65, 2019

ISSN: $1816-9155$

(C) Medwell Journals, 2019

\title{
Efficiency of Diallel and NCIII Mating Designs to Estimation of Gene Effects and Genetic Parameters in Rice (Oryza sativa L.)
}

\author{
${ }^{1}$ Alireza Haghighi Hasanalideh, ${ }^{2}$ Ezatollah Farshadfar and ${ }^{3}$ Mehrzad Allahgholipour \\ ${ }^{1}$ Young Researchers and Elite Club, Rasht Branch, Islamic Azad University, Rasht, Iran \\ ${ }^{2}$ Department of Production Engineering and Plant Genetics, \\ Faculty of Agricultural Sciences and Engineering, \\ Campus of Agriculture and Natural Resources, Razi University, Kermanshah, Iran \\ ${ }^{3}$ Department of Seed Improvement, Rice Research Institute of Iran, Agricultural Research, \\ Education and Extension Organization, Rasht, Iran
}

\begin{abstract}
Genetic parameters of some characters in rice evaluated with the use of two mating design: diallel and NCIII. Analysis of variance showed significant differences among genotypes for all studied traits in diallel and north NCIII mating design. The results of genetic parameter estimations for diallel mating design revealed the existence of additive-dominance effects in controlling studied traits. Relatively high broad sense heritability observed in Kernel Length (KL) and Final Viscosity (FV) trough diallel mating. The results of genetic parameter estimations for NCIII mating design showed the presence of additive-dominance effects in controlling of all studied traits. This results also indicated that the character's day to $50 \%$ of flowering (DTF) and FV controlled by over-dominance of gene effect. Broad-sense heritability was high for all traits and it had highest amount in KL through NCIII. The results of genetic parameters estimation of NCIII mating design approved results of diallel crossing method for FV in the existence of additive-dominance gene effects. Also, for DTF, the results of genetic parameters estimation through NCIII mating design confirmed results of diallel mating design. But it didn't apply for KL. Due to the lack of consistent conform of estimates for some traits, full following to the results of diallel designs will not lead to selecting good traits and effective breeding methods. Thus, according to the results of this study it suggested that the decision to select a breeding method for desirable traits based on the type of gene actions, made by using biparental progeny designs.
\end{abstract}

Key words: Genetic parameters, gene action, rice, diallel, NCIII design, biparental

\section{INTRODUCTION}

Rice is the second important crop in the world consumed by half of the world's population (Haghighi et al., 2017). FAO estimates revealed that world rice production in 2011 was 720 million tonnes and global production in 2025 should reach 800 million tonnes to meet global consumption (FAO, 2010). This increase in production should be accompanied by less land and water use. So, increasing rice production today is a major challenge. At least a $50 \%$ increase in rice production is due to the compatibility of the new varieties. Therefore, rice breeding is one of the important keys to increasing rice yield and adaptability (Haghighi et al., 2007). In a breeding program, knowing the gene effects of traits is crucial. By analyzing the combining ability and estimating the gene effect, one can select the appropriate parent and evaluate the importance of the yield and its components (Can et al., 1997). Knowing the main effect of the gene within the breeding population is in fact the key and guide to selecting breeding methods that result in the selection of high yielding varieties. In addition, if the action of genes is additive, selection of lines at different breeding levels can be effective in self-propagating plants because they have additive gene effects that can be transferred from one generation to another (Torres and Geraldi, 2007). Diallel crosses have been widely used by researchers to investigate the extent of combining and estimation of genetic parameters (Iqbal et al., 2007). It is usually difficult to obtain the right number of $F_{1}$ seeds in manually crossed plants. Therefore, several researchers have used the $\mathrm{F}_{2}$ generation to investigate. They also stated that $\mathrm{F}_{2}$ generation analysis yields more reliable results than $\mathrm{F}_{1}$ (Chao and Scott, 2000).

Random mating of $\mathrm{F}_{2}$ individuals or advanced generations (including two parents) are termed biparental mating and the results are termed biparental progenies. The basic concept of biparental mating is that the rare recombinants that are bound by the linkage imbalance are released by forced recombination and become available for selection in early segregating generations. The most important benefit of the biparental mating is to obtain

Corresponding Author: Alireza Haghighi Hasanalideh, Young Researchers and Elite Club, Rasht Branch, Islamic Azad University, Rasht, Iran, Mobile No: +98 9330825955 
accurate additive and dominance of genetic variance and average dominance. In 1948 and 1952, Comstock and Robinson developed three mating designs, namely, North Carolina I, II and II (NCI, NCII and NCIII). In each of these schemes, two important genetic parameters of additive genetic variance and dominance variance are estimated. In NCIII, a random population of $\mathrm{F}_{2}$ crossed with its inferred derivative lines. Maternal effects do not play a role in NCIII because males are selected. Since, the linkage is broken by the recursive crossing in this design, the estimation of the average degree of dominance and heritability is more accurate than the one and two North Carolina designs (Farshadfar, 2010). This is the most powerful design in North Carolina designs (Acquaah, 2012).

Pradhan et al. (2006) reported the presence of genes with additive and non-additive effects in controlling traits in rice. Manickavelu et al. (2006) by examining two-parent progeny in rice showed that traits days to $50 \%$ flowering, leaf curling and plant height were affected by additive gene effects. Torres and Geraldi (2007) using diallel crossing design showed that traits plant height, panicle length, number of grains per panicle, sterility rate and 1000-seed weight the contribution of dominant gene effects was more important while for the number of days to $50 \%$ flowering, the contribution of the additive effect was more important. Bagheri et al. (2008) using diallel mating for study of gene action and heritability of yield and related traits reported the presence of additive and non-additive effects of genes in controlling traits. Ahangar by examining different rice cultivars and genotypes in a $5 \times 5$ diallel arrangement indicated that genes with additive and non-additive effects are involved in controlling grain yield and its components. They also stated that among the traits evaluated, 1000-grain weight was controlled by non-additive genes. Salim et al. (2009) by examining the crossing of North Carolina in basmati rice, stated that biological yield is controlled by additive and non-additive gene effects. Tiwari et al. (2011) reported that there was a high degree of dominance for traits such as grain yield, number of panicles and biological yield, indicating that these traits were controlled by non-additive effects of genes. Mahalingam et al. (2012) by examining the progeny of two parental crosses in rice, showed that traits days to $50 \%$ flowering, plant height and number of fertilized panicles per plant in the first crossing, number of fertilized panicles per plant in The second crossing series is controlled by the additive action of genes. You et al. (2012) analyzed 11 rice lines using the North Carolina design and found that the cadmium content of brown rice has negative heterosis. Koli and Punia (2012) examined two progeny obtained from crosses of rice lines P$1460 \times 1121$ and reported higher average traits including number of panicle per plant, number of panicle, day to flowering, day to maturity and yield, they pollinate from their progeny. Kumar et al. (2013) performed an $8 \times 8$

diallel mating design and stating that due to non-additive and higher dominance than additive effects of genes on yield traits and yield components, suggested that biparental mating use to genetically improve these traits. Koli et al. (2013) examined $25 \mathrm{~F}_{2}$ populations from a cross of two parents P-1460-P-1121 that showed plant height, No. of panicles $/ \mathrm{m}^{2}$ and 1000 -seed weight are the best traits are to improve the yield of aromatic rice. Sultan et al. (2014) by examining the progeny of two parents, showed that for most of the traits, the controlling genes had incomplete dominance and over dominance effects.

By reviewing various sources, it was found that the results differed according to the studied populations. Therefore, this study was designed to obtain estimates of genetic parameters and the type of gene actions involved in important traits in rice using diallel crosses, then using North Carolina crosses with more accurate estimates of parameters, genetically, the reliability, validity or disapproval of the results of diallel crossing was determined.

\section{MATERIALS AND METHODS}

This study was carried out at Rice Research Institute of Iran, with longitude and latitude $49^{\circ} 36^{\circ} \mathrm{E}, 37^{\circ} 16^{\circ} \mathrm{N}$, $7 \mathrm{~m}$ high and silty clayey soil texture at $\mathrm{pH} 7$. The target lines were selected from 94 different rice genotypes grouped based on micro satellite markers (Allahgholipour et al., 2014) based on breeding objectives. In this study, 6 selected lines of rice research institute were used for diallel crossing design (Table 1). Also, two selected lines of Deylamani and Gilaneh were used to cross the NCIII.

The progeny obtained from the NCIII as well as the $\mathrm{F}_{2}$ progeny derived from the diallel crossing as a semidiallel design containing only direct crosses with their parents planted in a randomized complete block design with three replications in 2015. After necessary measurements, the results of Diallel, ANOVA test were used to determine the significant differences between genotypes. In case of differences, epistatic effect of genes was tested using parent-covariance regression line slope test. Their $\left(\mathrm{W}_{\mathrm{r}}\right)$ joint was performed on the Variance of rows $\left(\mathrm{V}_{\mathrm{r}}\right)$ of the unit slope. Also, $\mathrm{W}_{\mathrm{r}}-\mathrm{V}_{\mathrm{r}}$ and $\mathrm{W}_{\mathrm{r}}+\mathrm{V}_{\mathrm{r}}$ uniformity tests were performed using completely randomized analysis of variance to test for epistatic

Table 1: Name, origin of country and pedigree of rice genotypes used in this study

\begin{tabular}{|c|c|c|}
\hline Genotypes & Pedigree & Origin \\
\hline$\overline{\text { Gilaneh }^{\mathrm{a}}}$ & Saleh $^{\mathrm{a}} /$ Abjibojib//Abjiboji & RRII $^{\mathrm{c}}$, Iran \\
\hline Daylamani & Local cultivar & Mazandran, Iran \\
\hline IR50 & IR50 & IRRI $^{\mathrm{d}}$, Philippines \\
\hline Line 23 & IR75479-199-3-3 & IRRI, Philippines \\
\hline RI18447-2 & Sepidrood $^{\mathrm{a}} /$ Gharib $^{\mathrm{b}}$ & RRII, Iran \\
\hline RI18430-46 & Saleh $^{\mathrm{a}} /$ Hashemi $^{\mathrm{b}}$ & RRII, Iran \\
\hline
\end{tabular}


Agric. J., 14 (4): 60-65, 2019

effect and dominance, respectively. If the hypothesis of Hayman (1954) are confirmed, the parental distribution graph is drawn around the $\mathrm{W}_{\mathrm{r}}$ regression line on $\mathrm{V}_{\mathrm{r}}$. Genetic parameters of traits including additive and dominance variances and degree of dominance for each traits and broad sense and narrow sense heritability were estimated by Hayman (1954). Analysis of variance, estimation of variance components and genetic parameters were also performed in the NCIII to study the type of genes effects and the heritability of the traits. SPSS Software (IBM., 2011), Excel and Dial98 (Ukai, 2006) were used for analysis.

\section{RESULTS AND DISCUSSION}

Results of analysis of variance of days to $50 \%$ of flowering, kernel length and final viscosity in Diallel (Table 2) and NCIII (Table 3) indicate significant differences among genotypes for all traits were studied. The results of Diallell hypotheses by Hayman method (Table 4) showed that for traits days to $50 \%$ of flowering, kernel length and final viscosity, slope of regression line $\mathrm{W}_{\mathrm{r}}$ on $\mathrm{V}_{\mathrm{r}}$ was significantly different with zero and had not significant difference with one. Also, the significance of $\mathrm{W}_{\mathrm{r}}+\mathrm{V}_{\mathrm{r}}$ test and non-significance of $\mathrm{W}_{\mathrm{r}}-\mathrm{V}_{\mathrm{r}}$ test showed the presence of dominance effects and absence of epistatic effects in genetic control of studied traits. Based on the above results, the assumption of an additive-dominance genetic model for diallel genetic decomposition is proved. Biswas and Haque (2007) reported similar results. But Rani et al. (2015) reported the existence of epistatic effects on genetic control of kernel length. Kasture and Patel (2015) also reported epistatic effects for days to $50 \%$ of flowering. They also suggested the use of a biparental mating to improve rice traits. These differences appear to be due to the use of different parents in the crosses.

The results of estimating genetic parameters for studied traits in Diallel method (Table 5) showed that additive and dominance variance were significant for all traits, indicating that additive-dominance effects were in control of traits. However, given the greater variance of dominance than additive variance, it can be concluded that dominance effects were greater in controlling the studied traits. Allahgholipour and Ali (2006) estimated genetic variance components for grain length and number of days to $50 \%$ flowering, indicating that the dominance effect of genes in controlling these traits was superior to the additive effect. Allahgholipoour et al. (2011), by studying the genetic nature of the final viscosity characteristic, reported additive variance less than the dominance and environmental variance and stated that the dominance and environmental variance had more
Table 2: Analysis of variance for studied traits in rice genotypes through diallel mating design

\begin{tabular}{|c|c|c|c|c|}
\hline \multirow[b]{2}{*}{ S.O.V } & \multirow[b]{2}{*}{ df } & \multicolumn{3}{|l|}{ MS } \\
\hline & & $\begin{array}{l}\text { Days to } 50 \% \\
\text { of flowering }\end{array}$ & $\begin{array}{l}\text { Kernel } \\
\text { length }\end{array}$ & $\begin{array}{c}\text { Final } \\
\text { viscosity }\end{array}$ \\
\hline Genotype & 20 & $47.75^{* *}$ & $0.26^{* *}$ & $1524.84 * *$ \\
\hline Replication & 2 & $2.88^{\mathrm{ns}}$ & $0.01^{\mathrm{ns}}$ & $0.64^{\mathrm{ns}}$ \\
\hline Error & 40 & 2.78 & 0.01 & 83.34 \\
\hline
\end{tabular}

Table 3: Analysis of variance for studied traits in rice genotypes through, NCIII

\begin{tabular}{|c|c|c|c|c|}
\hline \multirow[b]{2}{*}{ S.O.V } & \multirow[b]{2}{*}{ df } & \multicolumn{3}{|l|}{ MS } \\
\hline & & $\begin{array}{l}\text { Days to } 50 \% \\
\text { of flowering }\end{array}$ & $\begin{array}{l}\text { Kernel } \\
\text { length }\end{array}$ & $\begin{array}{c}\text { Final } \\
\text { viscosity }\end{array}$ \\
\hline Replication & 2 & $4^{\mathrm{ns}}$ & $0.01^{\text {ns }}$ & $51.95^{\text {ns }}$ \\
\hline Males & 8 & $11.75^{* *}$ & $0.97 * *$ & $53.29 *$ \\
\hline Females & 1 & $249.19 * *$ & $0.11 *$ & $90.39^{*}$ \\
\hline Male $\times$ Female & 8 & $10.56^{* *}$ & $0.1 * *$ & $120.84 * *$ \\
\hline Error & 34 & 2.17 & 0.02 & 19.8 \\
\hline
\end{tabular}

Table 4: Results of preliminary test of Hayman, $t$ test $\left(\mathrm{H}_{0}: \beta=0\right)$, $\left(\mathrm{H}_{0}: \beta=1\right)$ for regression coefficients of $\mathrm{W}_{\mathrm{r}} / \mathrm{V}_{\mathrm{r}}$, test of dominance gene effects $\left(\mathrm{W}_{\mathrm{r}}+\mathrm{V}_{\mathrm{r}}\right)$ and epistatic $\left(\mathrm{W}_{\mathrm{r}}-\mathrm{V}_{\mathrm{r}}\right)$ and for the studied traits in rice through diallel mating design

\begin{tabular}{|c|c|c|c|c|c|}
\hline \multirow[b]{2}{*}{$\underline{\text { Traits }}$} & \multirow[b]{2}{*}{ (b) } & \multicolumn{2}{|l|}{$\mathrm{t}$-test } & \multirow{2}{*}{$\begin{array}{c}\mathrm{MS} \\
\left(\mathrm{W}_{\mathrm{r}}+\mathrm{V}_{\mathrm{r}}\right)\end{array}$} & \multirow{2}{*}{$\begin{array}{c}\mathrm{MS} \\
\left(\mathrm{W}_{\mathrm{r}}-\mathrm{V}_{\mathrm{r}}\right)\end{array}$} \\
\hline & & $\mathrm{H}_{0}: \beta=0$ & $\mathrm{H}_{0}: \beta=1$ & & \\
\hline$\overline{\mathrm{DTF}}$ & 1.013 & $5.446^{* *}$ & $-0.06^{\text {ns }}$ & $113.05^{* *}$ & $3.74^{\mathrm{ns}}$ \\
\hline KL & 0.99 & $5.076^{* *}$ & $0.025^{\mathrm{ns}}$ & $0.004 *$ & $0.0001^{\mathrm{ns}}$ \\
\hline FV & 0.82 & $3.942 * *$ & $0.888^{\text {ns }}$ & $903684.2^{* *}$ & $53403.6^{\mathrm{ns}}$ \\
\hline
\end{tabular}

Table 5: Genetic parameters estimations for the studied traits in rice through diallel mating design

\begin{tabular}{llcr}
\hline Genetic parameters & DTF & KL & FV \\
\hline D & $22.9^{* *}$ & $0.18^{* *}$ & $911^{* *}$ \\
$\mathrm{H} 1$ & $267^{* *}$ & $1.94^{* *}$ & $6790^{* *}$ \\
$\mathrm{H} 2$ & $82.4^{* *}$ & $0.29^{* *}$ & $4579^{* *}$ \\
$\mathrm{~F}$ & $7.35^{\text {ns }}$ & $0.16^{* *}$ & $2181^{* *}$ \\
$\mathrm{hh}$ & $35.6^{* *}$ & $0.04^{* *}$ & $837^{* *}$ \\
$\mathrm{E}$ & $0.95^{* *}$ & $0.00^{* *}$ & $30.1^{* *}$ \\
$0.25^{(\mathrm{H} / \mathrm{D})}$ & $0.49^{*}$ & $0.34^{* *}$ & $1.1^{* *}$ \\
$\mathrm{~h}$ & $-1.5^{\mathrm{ns}}$ & $0.05^{\mathrm{ns}}$ & $7.28^{\mathrm{ns}}$ \\
$\mathrm{h}^{2 \mathrm{~b}}$ & $74^{* *}$ & $0.86^{* *}$ & $0.85^{* *}$ \\
$\mathrm{~h}^{2 \mathrm{n}}$ & $0.25^{* *}$ & $0.31^{* *}$ & $0.55^{* *}$ \\
\hline
\end{tabular}

${ }^{n s}, *$ and $* *$ non-significant, significant at $5 \%$ and $1 \%$ probability level respectively, DTF: Day to 50\% Flowering, KL: Kernel length, FV: Final Viscosity, D: Additive variance, H1: Dominance variance, H2: Dominance variance, F: Relative frequency of dominant and recessive allels, hh: square of difference P vs. all, E Environment variance, 0.25 sqr (H1/D): Average degree of dominance, (h): Average direction of dominance, $\left(\mathrm{h}^{2 \mathrm{~b}}\right)$ : Broad-sense heritability, $\left(\mathrm{h}^{2 \mathrm{n}}\right)$ : Narrow-sense heritability

influence in controlling this trait. Estimates of mean degree of dominance showed that traits days to $50 \%$ flowering and kernel length were controlled by the effects of incomplete dominance of gene effect. Prasad (2014) 
Agric. J., 14 (4): 60-65, 2019
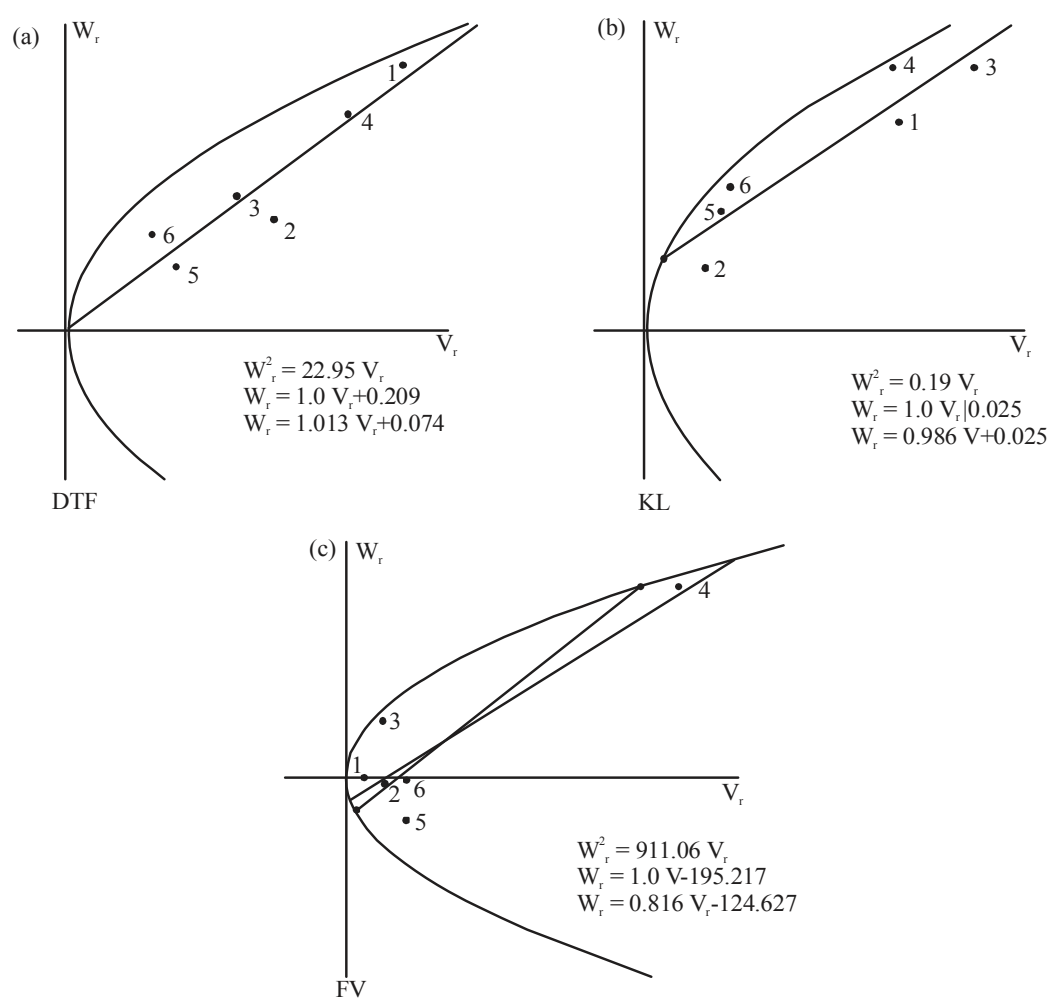

Fig. 1(a-c): Regression of $\mathrm{W}_{\mathrm{r}} / \mathrm{V}_{\mathrm{r}}$ for studied traits in rice genotypes trough diallel mating design; DTF: Day to 50\% flowering, KL: Kernel length, FV: Final viscosity, 1: Gilaneh, 2: Deylamani, 3: IR50, 4: Line 23, 5: RI18447-2, 6: RI18430-46

also reported incomplete dominance for days to $50 \%$ flowering. The high of this parameter (greater than one) for the final viscosity trait indicated the existence of overdominant effects in genetic control of this trait. These results were in agreement with the results of graphical analysis of $\mathrm{W}_{\mathrm{r}}$ regression on $\mathrm{Vr}$ (Fig. 1). The results of this study showed a relatively high broad sense heritability estimate for kernel length and final viscosity (Table 5). Gampala et al. (2015) also reported high broad sense heritability for kernel length. The low heritability of the studied traits confirmed the existence of dominant effects on genetic control of the traits. Results of graph analysis of $\mathrm{W}_{\mathrm{r}}$ on $\mathrm{V}_{\mathrm{r}}$ regression showed that according to parental distribution, Guilaneh parent had the most recessive alleles for days to $50 \%$ flowering and Deylamani parent had the most dominant alleles for kernel length. Also for the final viscosity, most dominant alleles were present in Gilaneh. The most recessive allele for this trait was found in line 23 . The proximity of the regression line to the single slope regression line also confirmed the suffdciency of graphical analysis results in all traits.

Estimation of genetic parameters for traits studied in the NCIII (Table 6) showed that additive and dominance variance were significant for days to $50 \%$ flowering
Table 6: Genetic parameters estimations for the studied traits in rice through, NCIII

\begin{tabular}{lrrr}
\hline Genetic parameters & $\mathrm{DTF}$ & $\mathrm{KL}$ & \multicolumn{1}{c}{$\mathrm{FV}$} \\
\hline $\mathrm{V}_{\mathrm{ml}}$ & $2.8^{* *}$ & $0.03^{* *}$ & $33.68^{* *}$ \\
$\mathrm{~V}_{\mathrm{m}}$ & $1.6^{* *}$ & $0.16^{* *}$ & $5.58^{*}$ \\
$\mathrm{D}$ & $6.39 * *$ & $0.63^{* *}$ & $22.32^{* *}$ \\
$\mathrm{H}$ & $5.59 * *$ & $0.06^{\mathrm{ns}}$ & $67.36^{* *}$ \\
$\mathrm{Dd}$ & $1.32^{* *}$ & $0.42^{* *}$ & $2.46^{\mathrm{ns}}$ \\
$\mathrm{h}^{2 \mathrm{~b}}$ & $0.85^{* *}$ & $0.97 *$ & $0.82 * *$ \\
$\mathrm{~h}^{2 \mathrm{n}}$ & $0.45^{*}$ & $0.89 * *$ & $0.9^{*}$ \\
\hline
\end{tabular}

ns,$*$ and $* *$ non-significant, significant at 5 and $1 \%$ probability level, respectively, DTF: Day to 50\% flowering, KL: Kernel length, FV: Final viscosity, $\mathrm{V}_{\mathrm{ml}}$ : variance of male $\times$ female interaction, $\mathrm{V}_{\mathrm{m}}$ : Male variance, D: Additive variance, H: Dominance variance, Dd: Dominance degree, $\left(\mathrm{h}^{2 \mathrm{~b}}\right)$ : Broad-sense heritability, $\left(\mathrm{h}^{2 \mathrm{n}}\right)$ : Narrow-sense heritability

and final viscosity. Therefore, it can be stated that dominance-additive effects play a role in controlling these traits. These results were consistent with the results of Islam (2015). Significant additive variance and non-significant dominance variance were observed for kernel length, indicating that additive effects in controlling this trait. Won and Yoshida (2000) reported additive and non-additive effects in controlling grain length traits. The high ratio of dominance variance to additive variance in the final viscosity trait confirmed the greater contribution of dominance effects in genetic control of this trait. Allahgholipour et al. (2011) also reported the contribution of additive variance less than the 
contribution of dominance and environmental variance in controlling final viscosity properties. Estimation of degree of dominance for the studied traits showed that traits days to $50 \%$ flowering and final viscosity were controlled by the suppressive effect of genes. However, this estimate was not significant for the final viscosity. Bagheri and Jelodar (2010) and Sharma and Mani (2001) also reported the highest contribution of non-additive effects in controlling these traits, which was consistent with the results of this study. Estimates of the degree of dominance smaller than one revealed the effects of incomplete dominance of genes in controlling kernel length. The broad sense heritability of all traits was relatively high and this parameter had the highest value for kernel length. These results are consistent with the results of Pandey and Anurag (2010). The results of the estimation of narrow sense heritability of traits showed that kernel length showed the highest narrow sense heritability. The low narrow sense heritability in the final viscosity trait confirmed the greater share of dominance effects in genetic control of the trait. Rabeie et al. (2004) reported similar results for broad sense heritability of seed length.

For trait days to $50 \%$ flowering, the results of estimating genetic parameters in NCIII confirmed the results of estimating the genetic parameters for the diallel crossing in the presence of additive-dominance effects. Although the share of additive effects in controlling this trait was higher in the NCIII, it was the opposite in the Diallell scheme (Table 5 and 6). The mean degree of dominance in the two designs revealed different results. But given the results of the $\mathrm{W}_{\mathrm{r}}$ regression on $\mathrm{V}_{\mathrm{r}}$ and very low values of the origin for this trait (Fig. 1) it can be ignored. In kernel length, the estimation of genetic parameters showed significant differences. However, estimation of degree of dominance in both mating designs showed incomplete dominance in controlling this trait, which was confirmed by the results of $\mathrm{W}_{\mathrm{r}}$ regression on $\mathrm{V}_{\mathrm{r}}$. The results of genetic parameters estimation in the NCIII confirmed the results of genetic parameters estimation for the diallel crossing method for the final viscosity trait and showed that this trait is controlled by the additive-dominance effects of genes and the share of dominance effects in this attribute is more. The parameter of mean degree of dominance for the final viscosity in both mating designs confirms the existence of over dominance. However, this parameter was not significant in the NCIII. The broad sense heritability in both crossing designs for days to $50 \%$ flowering, kernel length and final viscosity was consistent with the relatively high estimates. Estimates of narrow sense heritability in the NCIII for days to $50 \%$ flowering and kernel length showed higher values than the Diallel. But this was not the case for the final viscosity (Table 5 and 6). The inconsistency of estimation of genetic parameters for kernel length considering parental distribution over the slope of regression line (Fig. 1) can be attributed to the presence of dominant alleles in Deylamani parent and high recessive alleles in Gilaneh parent.

\section{CONCLUSION}

Due to the nature of the NC design and especially, the NCIII that used in this study, the estimated parameters of the traits have high accuracy and reliability. Therefore, due to the inconsistency of the estimates for some traits, mere compliance with the results of the Diallel will not result in optimal traits selection and appropriate breeding methods to improve traits. Therefore, according to the results of this study, it is recommended that the decision to choose breeding method according to the type of gene action for traits breeding be made using biparental progeny designs.

\section{REFERENCES}

Acquaah, G., 2012. Principles of Plant Genetics and Breeding. 2nd Edn., Wiley-Blackwell, Oxford, England, ISBN: 9781118313695, Pages: 760.

Allahgholipour, M. and A.J. Ali, 2006. Gene action and combining ability for grain yield and its components in rice. J. Sust. Agric., 28: 39-54.

Allahgholipour, M., B. Rabiei and M. Yekta, 2011. Assessment of general and specific combining abilities of the starch paste viscosity properties in parental lines of hybrid rice. Iran. J. Crop Sci., 13: 178-193.

Allhgholipour, M., E. Farshdfar and B. Rabiei, 2014. Molecular characterization and genetic diversity analysis of different rice cultivars by microsatellite markers. Genetika, 46: 187-198.

Bagheri, N. and N.B. Jelodar, 2010. Heterosis and combining ability analysis for yield and related-yield traits in hybrid rice. Int. J. Biol., 2: 222-231.

Bagheri, N., N.B. Jelodar and A. Ghanbari, 2008. Diallel analysis study of yield and yield-related traits in rice genotypes. Int. J. Agric. Res., 3: 386-396.

Biswas, P.S. and M.E. Haque, 2007. Gene action of agronomic traits in rice (Oryza sativa L.). Bangladesh J. Plant Breed. Genet., 20: 31-36.

Can, N.D., S. Nakamura and T. Yoshida, 1997. Combining ability and genotypexenvironmental interaction in early maturing grain sorghum for summer seeding. Jpn. J. Crop Sci., 66: 698-705.

Cho, Y. and R.A. Scott, 2000. Combining ability of seed vigor and seed yield in soybean. Euphytica, 112: 145-150.

FAO., 2010. Crop production statistics. Food and Agriculture Organization of United Nations, Rome, Italy. 
Farshadfar, E., 2010. [New Discussions in Biometrical Genetics]. Vol. 1, Islamic Azad University of Kermanshah Press, Iran, (In Persian).

Gampala, S., V.J. Singh and S.K. Chakraborti, 2015. Analysis of variability and genetic parameter for grain quality attributes in high yielding rice (Oryza sativa L.) genotypes. Ecoscan, 9: 411-414.

Haghighi, H.A., E. Farshadfar and M. Allahgholipour, 2017. Genetic parameters and combining ability of some important traits in rice (Oryza sativa L.). Genetika, 49: 1001-1014.

Hasanalideh, A.H., M. Allahgholipour and E. Farshadfar, 2019. Evaluating genetic parameters and combining ability of starch viscosity parameters in rice cultivars (Oryza sativa L.). Turk. J. Agric. Food Sci. Technol., 7: 665-671.

Hayman, B.I., 1954. The analysis of variance of diallel tables. Biometrics, 10: 235-244.

IBM., 2011. IBM SPSS Statistics for Windows, Version 20.0. IBM Corporation, Armonk, New York, USA.

Iqbal, M., A. Navabi, D.F. Salmon, R.C. Young and B.M. Mardoch et al., 2007. Genetic analysis of flowering and maturity time in high latitude spring wheat. Euphytica, 154: 207-218.

Islam, M.D.A., M.A.K. Mian, R. Golam, Q.A. Khaliq and M.A.M. Akanda, 2015. Estimation of gene action and variance components of some reproductive traits of rice (Oryza sativa L) through line $\mathrm{x}$ tester analysis. Rice Res., Vol. 3, No. 3. 10.4172/23754338.1000144

Kasture, A.G. and V.P. Patel, 2015. Genetic analysis of quality, yield and yield contributing traits in rice (Oryza sativa L.). Trends Biosci., 8: 5334-5340.

Koli, N.R. and S.S. Punia, 2012. Effect of intermating on genetic variability and character association in aromatic rice (Oryza sativa L.). Electron. J. Plant Breed., 3: 830-834.

Koli, N.R., B.L. Kumhar, R.K. Mahawar and S.S. Punia, 2013. Impact of biparental mating in aromatic rice (Oryza sativa L.). Int. J. Agric. Environ. Biotechnol., 6: 51-54.

Kumar, A., S. Singh and S.P. Singh, 2013. Genetic analysis of yield and quality traits in Basmati rice. Oryza Int. J. Rice, 50: 181-184.

Mahalingam, A., S. Robin, K. Mohanasundaram and R. Pushpam, 2012. Genetic variability and heritability in bi-parental progenies vs early segregating generations of rice (Oryza sativa L.) for important yield attributes. Madras Agric. J., 99: 192-196.

Manickavelu, A., N. Nadarajan, S.K. Ganesh and R.P. Gnanamalar, 2006. Genetic analysis of biparental progenies in rice (Orzya sativa L.). Asian J. Plant Sci., 5: 33-36.
Pandey, P. and P.J. Anurag, 2010. Estimation of genetic parameters in indigenous rice. Adv. Agric. Bot. Int. J. Bioflux Soc., 2: 79-84.

Pradhan, S.K., L.K. Bose and J. Meher, 2006. Studies on gene action and combining ability analysis in basmati rice. J. Central Eur. Agric., 7: 267-272.

Prasad, S., 2014. Gene action and combining ability analysis for yield and yield attributes in rice (Oryza sativa L.). M.Sc. Thesis, Department of Genetics and Plant Breeding, Narendra Deva University of Agriculture and Technology, Faizabad, India.

Rabiei, B., M. Valizadeh, B. Ghareyazie and M. Moghaddam, 2004. Evaluation of selection indices for improving rice grain shape. Field Crops Res., 89: 359-367.

Rani, P.J., P.V. Satyanarayana, N. Chamundeswari, M.L. Ahamed and M.G. Rani, 2015. Studies on genetic control of quality traits in rice (Oryza sativa L.) using six parameter model of generation mean analysis. Electron. J. Plant Breed., 6: 658-662.

Saleem, M.Y., J.I. Mirza and M.A. Haq, 2009. Triple test cross analysis of some physio-morphological traits in basmati rice (Oryza sativa L.). Pak. J. Bot., 41: 2411-2418.

Sharma, R.K. and S.C. Mani, 2001. Combining ability studies for grain yield and other associated characters in Basmati rice (Oryza sativa L.). Crop Improvement India, 28: 236-243.

Sultan, M.S., M.A. Abdel-Moneam, A.B. El-Abd and S.A. El-Naem, 2014. Inheritance of some root and grain quality traits in rice under water deficiency conditions. J. Agron., 13: 89-99.

Tiwari, D.K., P. Pandey, S.P. Giri and J.L. Dwivedi, 2011. Prediction of gene action, heterosis and combining ability to identify superior rice hybrids. Int. J. Bot., 7: 126-144.

Torres, E.A. and I.O. Geraldi, 2007. Partial diallel analysis of agronomic characters in rice (Oryza sativa L.). Genet. Mol. Biol., 30: 605-613.

Won, J.G. and T. Yoshida, 2000. Combining ability in the rice lines selected for direct-seeding in flooded paddy field. Plant Prod. Sci., 3: 366-371.

You, S., Y. Cao, K. Jiang, J. Zheng and X. Wu et al., 2012. Analysis of heterosis, combining ability and heritability of cadmium content in brown rice of three-line indica hybrid rice. Agric. Sci. Technol., 13: 2358-2362. 